\title{
頭蓋下顎障害 $(\mathrm{CMD})$ と矯正に際して \\ 前準備として行う押圧法について
}

岡永覚

\section{Craniomandibular Disturbance (CMD) and the Finger Pressure Method as Pretreatment for Its Correction}

\section{Satoru Okanaga}

In the treatment for $\mathrm{CMD}$, treatment before application of chiropractic is necessary. Muscle tension should be adequately removed by the finger pressure method before correction.

We report a patient in whom the finger pressure method was perfomed before correction of the temporomandibular joint.

The finger pressure method before correction of the joint improved the range of motion of the joint and allowed unstrained correction using the improved motion. In addition, pain was reduced

\section{はじめに}

日常の Craniomandibular disturbance (以下 $\mathrm{CMD}$ と略す）の臨床において，カイロプラク ティックや整体術が応用されることはあまりな い. また, 姿勢と CMD との関連性が臨床で考慮さ れることも少ない.しかし，カイロプラクティッ クや整体術, 理学療法の分野は, 姿勢と CMD の関 連が重要視され, カイロプラクティックや整体術 では, 顎関節自体に矯正も行われている ${ }^{1 \sim 7)}$.いつ たい,このギャップはどこから来るのだろうか.

著者は,世間一般において,カイロプラクティッ クや整体術に対する誤解から来る偏見が少なから ず存在していると考える.また, 医師, 歯科医師 などの間でも, カイロプラクティックや整体術が 広く正しく理解されているとは言い難い実状を考 えると，それも仕方のないことかもしれない。
しかし，カイロプラクティックや整体術は，一 部マスコミがおもしろ半分に取り上げているよう に「力まかせに，無理に骨格を矯正する」ような 暴力的な手技では決してない。そのような誤解か ら来る偏見を改め, 歯科の臨床にカイロプラク ティックや整体術を抵抗なく取り入れられるよう に, 著者の顎関節矯正法の治療の流れとその背景 にある考え方を紹介する。

\section{方法}

カイロプラクティックや整体術で, 実際に骨格 を矯正する前にしておくことがある，術前に赤外 線やホットバックなどの温熱療法や牽引療法を施 すことがある ${ }^{8,9)}$. あるいは, 手指にて押圧するこ とがある ${ }^{10 \sim 15)}$. そこで今回は, 顎関節の矯正に入 る前に行う押圧法の 1 症例を報告する.この方法 は, 顎関節のほか, 頸椎の矯正が必要なケースで あっても，応用が可能である。

以下，実際の術式を説明する。 


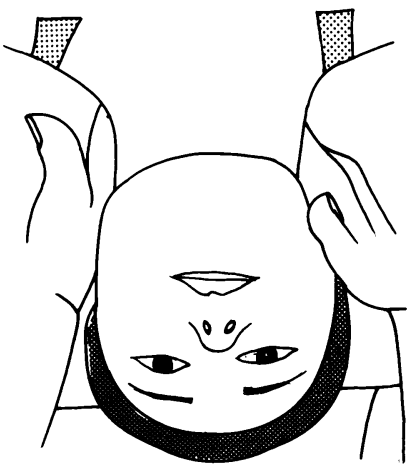

図 1 頸部浸透押圧法



図 3 肩井穴浸透押圧法

\section{1. 準備}

ユニットの上に患者を座らせ，ユニットを水平 に倒す（もし，マッサージ台があるのならば，そ のほうが望ましい).

\section{2. 頸部漫透押圧法}

頸椎後部の側面を両手でさぐり, 固いほうを揉 みほぐす(図 1)。

\section{3. 百会穴漫透押圧法}

頭頂の百会を，両親指にて押圧する（図 2).

・百会は, 頭蓋の頂点, 両耳尖を結ぶ線と正中 線との交差する陥凹部にある，両耳孔へ中指を差 し入れ，両親指で頭を抱え込むようにしたとき， 両親指が合わさった所が百会に相当している.

\section{4 . 肩井穴浸透押圧法}

両肩の肩井を，両親指にて押圧する（図 3).

・肩井は，肩上面の中央にある、鎖骨肩峰端と 第六頸椎突起の中間より約 $1 \mathrm{~cm}$ 頸椎に近い所で ある。

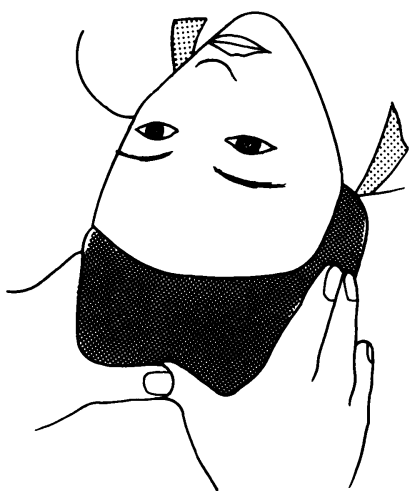

図 2 百会穴浸透押圧法

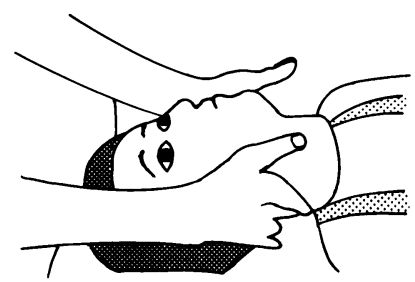

図 4 頸椎部調整矯正法

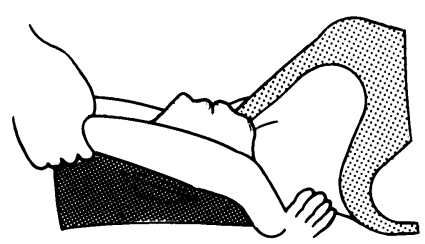

図 5 頸椎部タオル伸展法

\section{5. 頸椎部調整矯正法}

頸椎を下から順番に持ち上げる（図 4).

\section{6. 頸椎部タオル伸展法}

患者の後頭部にタオルを入れて両端を額の辺り でねじり，軽く引っ張る（図5)。その際，患者に 力を抜いてもらうこと.

\section{7、䫫部筋側屈伸展法}

後頸部を片手で㣣み持ち，その手のほうへ側届 させて固定させた後，他方の手で肩部を押さえ， 下方に押し下げる (図6)。

\section{8. 顔面部経穴漫透押圧調整法}

頭維，糸竹空，太陽，下関，聴宮，鷖風，観髎， 


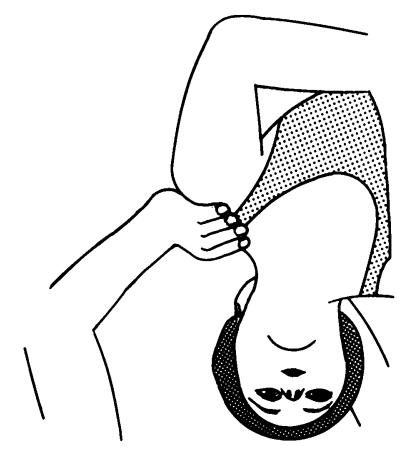

図 6 頸部筋側届伸展法

治聾四，大迎そして煩車などの経穴のほか，下顎 角内側, 耳の後ろの関節頸後縁を押圧する (図 7).

-頭維は, 前頭部正中線の側方約 $8 \mathrm{~cm}$ で, 髪際 から約 $1 \mathrm{~cm}$ 入った所にある.

・系竹空は, 眉毛の外側端にある。

-太陽は, 眉尻と外眼角の間の後方約 $2 \mathrm{~cm}$ の 陥凹部である。

・下関は，煩骨弓の下縁にある凹みで，下澦骨 頭の前方に当たる．この凹みは口を開けると消失 するので，口を閉じて取穴する。

・聴宮は, 耳珠の中点と顎関節の間で，口を開 けたときにできる陥凹部である。

・鷖風は，耳染の下，顎骨の後縁にある.

・観髎は, 外眼角の下方で, 煩骨弓の下縁を越 えた凹みである。

・治望四は，耳垂下の下顎枝骨面にある。

・大迎は, 下顎角と口角のほほ中央, 下頡角の 前方約 $4 \mathrm{~cm}$ にある.

・煩車は, 下顎角前上方約 1 横指，咀嚼の際に みられる筋性隆起のある所である。

以上，顎関節の矯正に入る前の押圧法について 述べてきた。この後, 通法により顎関節の矯正, 必要ならば頸椎の矯正も行う。特殊なカイロテー ブルを使用しないとできない手技もあるが，ユ ニット上でも十分にできる手技も少なくな ( ${ }^{4,5,7)}$.

\section{考察}

靧関節の変位, あるいは頸椎の変位は, 骨格の みがずれているのではない. 今一度，骨格がずれ

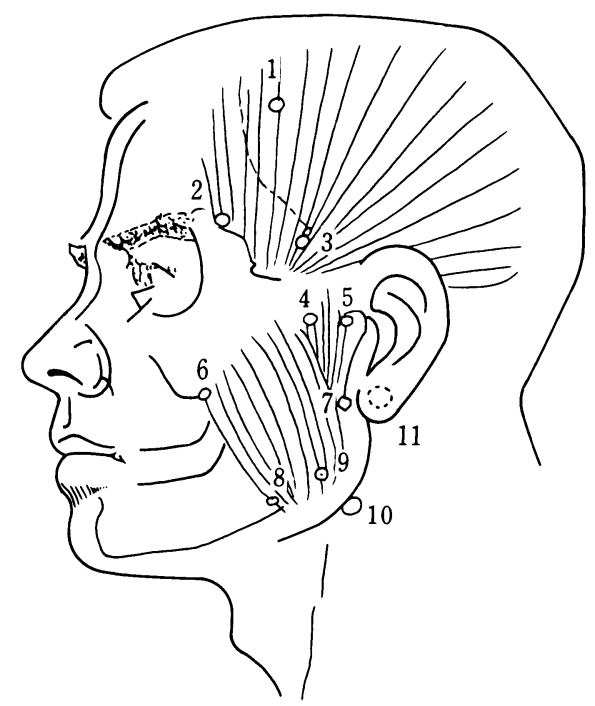

図 7 顔面部経穴浸透押圧調整法（文

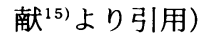

1. 頭維, 2. 系竹空, 3. 太陽, 4. 下関，5．聴宮，6。観髎，7．治聾四， 8. 大迎, 9. 煩車, 10. 下顎角内側, 11. 耳の後乃, 関節頸後緑

ている原因を考えてみよう。

骨と骨とが関節を作り，骨には筋肉が付いてい る。筋肉が異常に緊張すると, それに引っ張られ て骨格が変位する．言い換えると，筋肉の異常な 緊張が骨格を変位させる原因であるとも考えられ る.カイロプラクティックでは，骨格を矯正する ことで筋肉の異常な緊張が取れるという考え方も あるが，筋肉の緊張が関節の可動域を少なくし， 骨格の矯正を困難にしているのも事実である。し たがって，筋肉の緊張を緩和し，関節の可動域を 改善させ，その遊びを利用した矯正を心掛けるこ とによって，無理のない安全な矯正に努めること が大切だと思う、筋肉が緊張した状態で，それに 逆らう無理な力を強引に加えると，かえって筋肉 を緊張させ，患者に苦痛を与えるばかりでなく， 筋肉に損傷を与えたりして, 期待どおりの効果が 得られなくなることさえある。

それでは，どのようにして筋肉の緊張を取り除 いたらよいのだろうか. 著者は，診査に続いて行 われる術前の赤外線やホットバックなどの温熱療 法, 牽引療法, 押圧法などを入念に行うことで筋 肉の緊張が緩和できると考えている，特に，手指 
による押圧は, 筇肉の緊張状態を触診しながら施 術できるので，臨床上有用で，著者は多用してい る.もっと, 矯正の前準備としてのこれらの療法 を重要視するべきだと思う。

\section{まと め}

CMD の治療で，カイロプラクティックや整体 術を応用するときには, 実際の矯正に入る前に手 指にて押圧し,筋肉の緊張を取り除くべきである. そうすることによって, 無理のない安全な矯正が 可能となる，もちろん，患者に与える苦痛も少な くなる.

\section{参考文献}

1）川添堯椡,ほか：生理学的咬合へのアプローチ. 医歯薬出版 (東京), 1992.

2）小林俊三，ほか：䪽関節症のすべて.デンタル ダイヤモンド (東京), 1982.

3）上村修三郎，ほか：額関節小事典 II. 日本歯科 評論 (東京), 1993.

4) Kim, D. C. : クリニカルカイロプラクティック テクニック。132-136, 医道の日本社（東京),
1990.

5） Freddy, M. K.：四肢関節のマニュアルモビリ ゼーション. 217-223, 医歯薬出版(東京), 1988.

6) Tore, L. H., ほか：頭蓋下顎障害 (CMD) の理 学療法.クインテッセンス出版 (東京), 1992.

7）山田唯勝：咬合整体療法の基礎.エンタプライ ズ (東京), 1996.

8）松村 秩, ほか：理学療法. 125-195, 医歯薬出 版 (東京), 1995.

9) Kim, D. C. : クリニカルカイロプラクティック テクニック４40-49，52，医道の日本社(東京), 1990.

10）井芹 茂：整体術教本. 健友館（東京），1993.

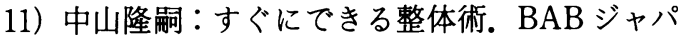
ン (東京), 1996 .

12）佐藤 彰：スポーツ整体・家庭整体.ベースボー ルマガジン社 (東京), 1995.

13）佐藤 彰：手当てとテープ. ベースボールマガ ジン社 (東京), 1996.

14）丸茂 畺：背中にふれて病気を治す.農文協(東 京), 1990 .

15）口腔䅡顔面外科学：284-287, 四川医学院（中 国)，1974。

別刷請求先：岡永 覚

岡永歯科 